\title{
First report on the nematode-trapping fungus, Arthrobotrys javanica, from the Soil of Ulleung Island, Korea
}

\author{
Hai-Yan $\mathrm{Wu}^{1}$, Dong-Geun $\mathrm{Kim}^{2 \star}$ and Xun-Bo Zhou ${ }^{3^{*}}$ \\ ${ }^{1}$ Agricultural College of Guangxi University, Nanning 530004, China. \\ ${ }^{2}$ Institute for Natural Products Research, Gyeongbuk Agricultural Technology Administration, Sangri-ri 133-6, Euiseong, \\ Korea. \\ ${ }^{3}$ State Key Laboratory of Crop Biology, Shandong Agricultural University,Taian 271018, China.
}

Accepted 22 November, 2012

\begin{abstract}
Arthrobotrys javanica captures nematodes in adhesive networks. This fungus was isolated from the soil around the root of Dystaenia takeshimana in Ulleung Island, South Korea. It produces 1-septate conidia with a size of $31.1 \times 12.0 \mu \mathrm{m}$ on a candelabrum-like apical branch. This feature distinguishes $A$. javanica from other species of Arthrobotrys. Chlamydospores were observed $(d=17 \mu \mathrm{m})$, which were not previously mentioned in the original description. The present study is the first report on $A$. javanica in Korea.
\end{abstract}

Key words: Arthrobotrys javanica, nematode-trapping fungus, adhesive network.

\section{INTRODUCTION}

Nematode-trapping fungi are ubiquitous in soil environments. They have been studied worldwide because of their potential applications as bio-control agents for plant and animal parasitic nematodes (Mankau, 1980; Bordallo et al., 2002; Soder et al., 2005). These fungi capture nematodes by three-dimensional networks, adhesive columnar branches, adhesive knobs, constricting rings, and non-constricting rings. They digest the internal organs of nematodes and form reproductive cells. Few studies on nematode-trapping fungi are available in South Korea.

The main objective of this study was to describe morphological characters of a potential fungus, which was collected during survey of bio-control fungi for plantparasitic nematodes in Korea in 2009.

\footnotetext{
*Corresponding author. E-mail: kimdgkr@naver.com or whyzxb@yahoo.com.cn.
}

\section{MATERIALS AND METHODS}

Fresh soil around the root of $D$. takeshimana was collected in Ulleung Island, Korea on August 2009. The nematode-trapping fungi were isolated through a modified sprinkling-baiting technique (Barron, 1977). Subsamples of $1.0 \mathrm{~g}$ soil were sprinkled onto plates of both $1.7 \%$ corn meal agar (CMA, Difco) and $2 \%$ water agar (WA). About 200 nematodes (Rhabditis spp.) were added to the surface of Petri dish plates $(D=10 \mathrm{~cm})$ as bait for the nematode-trapping fungi. Two CMA and two WA plates were used for each soil sample. The plates were incubated for two to four weeks at $25^{\circ} \mathrm{C}$ and examined every other day under a dissecting microscope (Olympus $\mathrm{SZ} \times 12)$ to detect the appearance of nematode-trapping fungi. All detected nematode-trapping fungi were photographed using an attached digital camera (Nikon DXM1200F), and transferred to CMA for pure culture. A new recorded species of nematode-trapping fungus was isolated. The description of this species is presented in the current paper.

\section{RESULTS AND DISCUSSION}

The taxonomic revisions of this species are given below: 

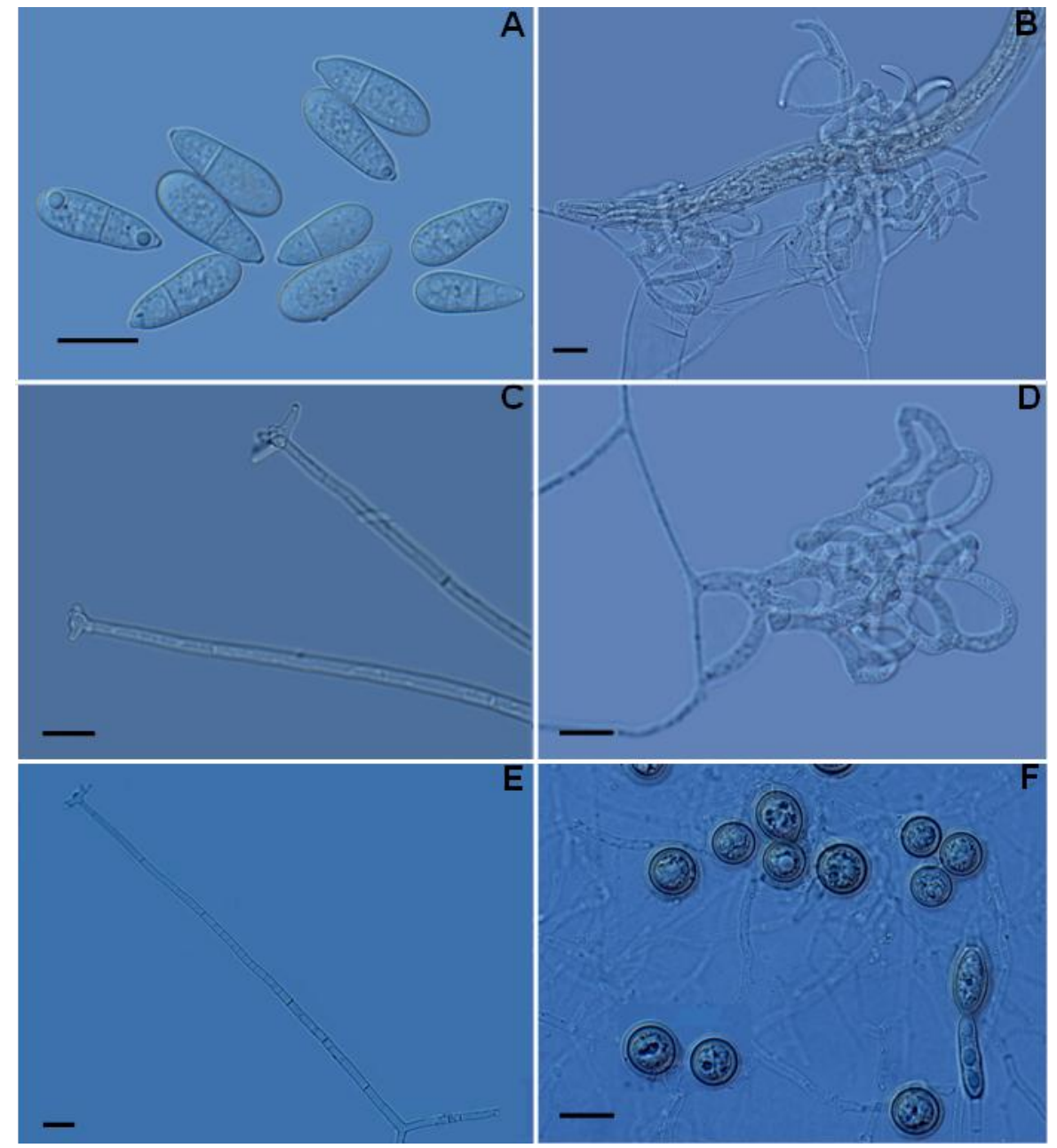

Figure 1. Arthrobotrys javanica. A, conidia; B, partially digested nematode captured by adhesive network; C and E, conidiophores; D, adhesive network; F, chlamydospores. Bars $=20 \mu \mathrm{m}$.

\section{Arthrobotrys javanica}

1. Candelabrella javanica (Rifai and Cooke, 1966).

2. Arthrobotrys javanica (Jarowaja, 1970).

The mycelium was hyaline, septate, branched, smooth walled, and 3 to $7 \mu \mathrm{m}$ in diameter. The conidiophores were erect, straight, subulate, 275 to $440 \mu \mathrm{m}$ high, approximately $9 \mu \mathrm{m}$ wide at the base, and gently attenuating to 2 to $3 \mu \mathrm{m}$ near the apex. They were hyaline, smooth and slightly enlarged as ramification occurred, and bearing a lax, short, candelabrum-like apical branching system. The conidia arose singly as blown-out ends of the conidiophore and the subsequently developed growing points. They were narrowly obovoid, 1 -septate, 25.0 to $42.5 \mu \mathrm{m}$ long, 10.0 to $15.6 \mu \mathrm{m}$ wide, slightly constricted at the septum, rounded distally with the obconical basal cell tapering to a truncate base, smooth walled and hyaline. In pure culture on CMA, the conidia were smaller, up to $35 \mu \mathrm{m}$ long and 11.3 to $13.8 \mu \mathrm{m}$ wide. The detached conidia left behind subcylindrical conidial pegs up to 15 $\mu \mathrm{m}$ long and approximately $2 \mu \mathrm{m}$ in diameter. The fungus trapped nematodes by means of adhesive networks.

This species was originally described by Rifai and Cooke (1966) from the soil in Bogor Botanic Garden, Java, on sterile rabbit dung agar. The fungus in this study identified as $A$. javanica was first isolated from the soil around Dystaenia takeshimana in Ulleung Island, Korea. The fungus produces narrowly obovoid large conidia on the surface of CMA. The conidiophores characteristics (Figures $1 \mathrm{~A}$ and $\mathrm{B}$ ), conidia shape (Figure $1 \mathrm{C}$ ), and threedimensional adhesive networks (Figures 1D and E) well fitted with Rifai and Cooke's description of $A$. javanica. Slight differences were observed on the conidia and conidiophores but within the range of $A$. javanica Jarowaja originally described by Rifai and Cooke (1966).

Chlamydospores were not mentioned in the original description. In the present study, the chlamydospores were observed at 50 days after incubation at $25^{\circ} \mathrm{C}$ on 
Table 1. Comparison of Arthrobotrys javanica isolates from Korea with the original description and its closely related species Arthrobotrys musiformis (Rifai and Cooke, 1966).

\begin{tabular}{llcccc}
\hline \multirow{2}{*}{ Character } & & Korea isolate & & \multicolumn{2}{c}{ Original description } \\
\cline { 3 - 3 } \cline { 5 - 6 } & & (Range) & & A. javanica (Range) & A. musiformis (Range) \\
\hline Conidiophores & Length $(\mu \mathrm{m})$ & $359.6(207.4-528.2)$ & & $275.0-440.0$ & Up to 600 \\
\hline Conidia & Length $(\mu \mathrm{m})$ & $31.1(24.9-38.3)$ & & $25.0-42.5$ & $29.0-45.0$ \\
& Width $(\mu \mathrm{m})$ & $12.0(10.5-15.5)$ & & $10.0-15.6$ & $8.0-13.5$ \\
\cline { 2 - 3 } & Shape & Narrowly obovoid & & Narrowly obovoid & $\begin{array}{c}\text { Ellipsoid or narrowly obovoid, } \\
\text { generally curved }\end{array}$ \\
& Septa & 1, slightly constructed & & 1, slightly constructed & 1, non-constructed \\
\hline Chlamydospores & & Thick walled, smooth, globose, or & None reported & Thick-walled, tuberculated, and \\
& & elongate ovoid & & & globose \\
\hline
\end{tabular}

CMA (Figures 1F). Generally, thick-walled, smooth, yellow, and $17.0 \mu \mathrm{m}$ in diameter globose chlamydospores are produced terminally on short lateral hypha, along with less frequent elongate ovoid chlamydospores $(27.6 \times 19.0 \mu \mathrm{m})$. Among the species in the genus Arthrobotrys, only $A$. javanica and Arthrobotrys musiformis produced conidia on candelabrum-like apical branches (Figures $1 \mathrm{~A}$ and $\mathrm{B}$ ), with adhesive networks. However, $A$. javanica is different from $A$. musiformis. The conidium of $A$. javanica is shorter, wider, not curved, and slightly constricted at the septum (Table 1) (Rifai and Cooke, 1966).

\section{ACKNOWLEDGEMENTS}

This study was sponsored by the National Natural Science Foundation of China (31101420), the Special Fund for Agro-scientific Research in the Public Interest
(200903040), the Technology Program of the Higher Education Institutions of Shandong Province (J11LC23), and the Korean-China Scientist (Post-doc.) Exchange Program.

\section{REFERENCES}

Barron GL (1977). Nematode-destroying fungi. Tropics in Mycobiology No. 1. Lancaster Press, Inc., Lancaster Pennsylvania.

Bordallo JJ, Lopez-Llorca LV, Jansson HB, Salinas J, Persmark L, Asensio L (2002). Colonization of plant roots by egg-parasitic and nematode-trapping fungi. New Phytol. 154:491-499.

Jarowaja N (1970). The genus Arthrobotrys Corda. Acta Mycol. 6:373.

Mankau R (1980). Biocontrol: fungi as nematode control agents. J. Nematol. 12:244-252.

Rifai MA, Cooke RC (1966). Studies on some didymosporous genera of nematode-trapping hyphomycetes. Trans. Br. Mycol. Soc. 49:147-168.

Soder KJ, Holden LA (2005). Use of nematode-trapping fungi as a biological control in grazing livestock. Prof. Anim. Sci. 21:30-37. 